\title{
Phytochemical Constituents, Antimicrobial activities and Isolation of Eupatorin from the Seed Extract of L. inermis LINN
}

\author{
"OCHU, RS; IBRAHIM, H; OYEWALE, AO \\ Department of Chemistry, Ahmadu Bello University, Zaria, Kaduna State, Nigeria. \\ *Corresponding Author Email: ochureal@gmail.com; Tel: 08036335948,08175312910
}

\begin{abstract}
In low- and middle-income countries like Nigeria, traditional medicine practitioners use seeds, roots, stem barks or the whole plant to cure some ailments, hence, the need to scientifically analyze these ethnobotanical claims. The extracts of L. inermis revealed the presence of cardiac glycosides, saponins, flavonoids tannins, triterpenes, steroid and alkaloids. The antimicrobial screening and activities of the crude extracts were observed against Staphylococcus aureus, Bacillus subtilis, Escherichia coli, Salmonella typhi, Pseudomonas aeruginosa, Klebsiella pneumonia with a zones of inhibition ranging from 12-26 mm which were however lower than the standard drug (Ciprofloxacin) with 28-30 mm. The MIC/MBC measurement against those microbes was found to be between $3.125 \mathrm{mg} / \mathrm{ml}$ to $50 \mathrm{mg} / \mathrm{ml}$. The ethyl acetate extract was purified using column chromatography and eluted with ethyl acetate and ethanol solvents in various ratios. From the fractions obtained, the compound eupatorin (3',5-dihydroxy-4',6,7-trimethoxyflavone) was isolated and characterized using IR, 1D and 2D NMR. The eupatorin was found to show significant microbial activity against $\mathrm{P}$. vulgaris, S. typhi, E. coli, S. pneumonia and S. pyogenes when compared with standard antibiotics used against these microbes. The results from this research have supported the ethnomedicinal uses of this plant in the treatment of skin infections, abdominal disorders, leprosy, rheumatalgia, edema and as a cough and cold remedy.
\end{abstract}

\section{DOI: $\underline{\text { https://dx.doi.org/10.4314/jasem.v23i12.4 }}$}

Copyright: Copyright (C) 2019 Ochu et al. This is an open access article distributed under the Creative Commons Attribution License (CCL), which permits unrestricted use, distribution, and reproduction in any medium, provided the original work is properly cited.

Dates: Received: 10 November 2019; Revised: 11 December 2019; Accepted: 20 December 2019

Keywords: Lawsonia inermis, phytochemicals, antimicrobial screening, Eupatorin

Medicinal plants are part and parcel of any generation of human being in the society used in order to combat various diseases from the dawn of civilization (Bandyopadhyay et al., 2002). Medicinal plants are known to their curatives potentials to certain biological active substances which exist in part of the plants. Traditional medicine is the ancient method of curing diseases and infections in which various plant have been used in different part of the world (Nwenze et al., 2004; Vineela and Elizabeth, 2005). Medicinal plants are of great importance to health of individuals and communities. In low- and middle-income countries like Nigeria, traditional medicine practitioners use seeds, roots, stem barks or the whole plant to cure some ailments where modern medicine may not be enough to meet the health care challenges. Traditional medicine is perceived to be more affordable, accessible and acceptable to the communities in which it operates (Sato, 2012). Many of these indigenous medicinal plants are used as spices and food meant for pregnant and nursing mothers for medicinal purposes (Okwu, 1999, 2001). Lawsonia inermis is commonly known as Henna. It is a flowering plant, having a height of 5 meters. The leaves are small about 1.5 to $5 \mathrm{~cm}$ long, 0.5 to $2 \mathrm{~cm}$ wide, greenish-brown in colour. Henna shrub is highly branched and has grayish-brown barks (Muhammad and Muhammad, 2005). It is a biennial dicotyledonous herbaceous shrub which solemnly grow in the native of North Africa and South-West Asia. The plant henna is widely cultivated throughout the tropical and subtropical region as an ornamental and dye plant. In folk medicines, henna has been used as astringent, anti-hemorrhagic, intestinal antineoplastic, cardioinhibitory, hypotensive, sedative and also as therapeutic against amoebiasis, headache, jaundice and leprosy (Simon et al., 1984; Rao et al., 2005).

The leaves of the plant have been used for the treatment of various ailments such as antiinflammatory, leprosy, rheumatalgia, edema, antiulcer, anti-helminthic, anti-cancer, anti-typhoid, antimalaria, anti-diarrhea, cough, bronchitis and antitumor (Reddy, 1988 and Warrier, 2004). Statistic has shown that $80 \%$ of the world's population use traditional medicine to meet their primary healthcare needs and these has gone to the extent of been use in policy-making (King and Homsy, 1997; Kim et al., 2014). The essential oil of the leaf of L. inermis was reported in the literature to contain some compounds such as lawsone, ethyl hexadecanoate, methyl cinnamate, ioscaryophellene, E-beta-inone and methyl linolenate (Oyedeji et al., 2005). 


\section{MATERIALS AND METHODS}

The seeds of L. inermis was collected from Adavi Local Government Area, Kogi State, Nigeria. The seeds were identified at the Herbarium unit of the Department of Botany, Faculty of Life Science, Ahmadu Bello University, Zaria, Kaduna State, Nigeria, with voucher number of 900270 . The seeds were air dried under shade at a temperature of $37^{\circ} \mathrm{C}$ for 7 days and pulverized into powdered (Girish and Satish, 2008). The powdered seed material was successively extracted with n-hexane, chloroform, ethyl acetate and methanol by cold maceration method for $48 \mathrm{hrs}$ each. The extracts were concentrated using a rotary evaporator and allowed to dry. All extracts were stored in a rap vial swapped in foil paper.

Preliminary phytochemical screening: The extracts was subjected to preliminary phytochemical screening using standard methods for the detection of various plant constituents such as alkaloids, tannins, flavonoids, cardiac glycosides, saponins, anthraquinones, steroids and triterpenes (Evans, 1987, 1997; Trease and Evans, 1989; Dey and Harborne, 1987; Finar, 1986).

Antimicrobial Screening: Preparation of Plant Extracts for Antimicrobial screening test: The antibacterial activity was evaluated using Staphylococcus aureus, Escherichia coli, Klebsiella pneumonia, pseudomonas aeruginosa, Bacillus subtilis, Streptococcus pyogenes, and Salmonella typhi, Candida albican. The antimicrobial screening was carried out using the agar diffusion method (NCCLS, 2000) with slight modifications. Overnight culture of the various bacteria in blood agar and the fungi in dextrose agar slant media were sterilized at $121^{\circ} \mathrm{C}$ for 15 minutes. The sterilised media were then seeded with $0.1 \mathrm{~mL}$ standard inoculum of the test microorganism. The inoculum was spread evenly over the surface of the seeded media by the use of a sterile swab. By the use of a standard cork-borer of $6 \mathrm{~mm}$ in diameter, a well was cut at the center of each seeded medium and $0.1 \mathrm{~mL}$ solution of the compound was then introduced into each well on the medium. The inoculated plates were incubated at $37{ }^{\circ} \mathrm{C}$ for 24 hours, after which the plates were observed for the zone of inhibition of growth of microorganisms. The zone was measured with a transparent ruler and the result recorded in millimeters (Perez et al., 1990).

Determination of Minimum Inhibitory Concentration (MIC) of the compounds: Minimum inhibitory concentration of the compounds was carried out on the test organisms using the broth dilution method as described by Vollekova et al. (2001). In this method, $10 \mathrm{~mL}$ nutrient broth (prepared using manufacturer's specifications) was dispersed into test tubes and sterilized at $121{ }^{\circ} \mathrm{C}$ for 10 minutes and allowed to cool. McFarland's turbidity standard scale number 0.5 was prepared to give a turbid solution. Normal saline (10 $\mathrm{mL}$ ) was dispensed into sterile test-tube and the test microbes inoculated and incubated at $37^{\circ} \mathrm{C}$ for $6 \mathrm{hrs}$. Dilution of the test microbes in the normal saline was made until the turbidity matched that of the McFarland scale by visual comparison. This dilution resulted in the test microbes having a concentration of $1.5 \mathrm{x}$ $10^{8} \mathrm{cfu} / \mathrm{mL}$. Two-fold serial dilutions of the compounds in the sterile broth was made to obtain concentrations of $20 \mathrm{mg} / \mathrm{mL}, 10 \mathrm{mg} / \mathrm{mL}, 5 \mathrm{mg} / \mathrm{mL}, 2.5$ $\mathrm{mg} / \mathrm{mL}$ and $1.25 \mathrm{mg} / \mathrm{mL}$. Having obtained the different concentration of the compound in the serial broth, 0.1 $\mathrm{mL}$ of the test microbes in the normal saline was then inoculated into the different concentrations of the compounds. Incubation was made at $37{ }^{\circ} \mathrm{C}$ for $24 \mathrm{~h}$ after which each test-tube was observed for turbidity (growth). The lowest concentration of the compounds in the broth which shows no turbidity was recorded as the minimum inhibitory concentration. The experiment was conducted in triplicates for all the concentrations.

Minimum Bactericidal Concentration (MBC): Mueller-Hinton agar was prepared, sterilized and poured into sterile petri. The plates were allowed to cool and solidify. The content of the MIC in the serial dilution were then sub-cultured onto the prepared medium. Incubation was made at $37{ }^{\circ} \mathrm{C}$ for $24 \mathrm{~h}$ after which each plate was observed for colony growth. The $\mathrm{MBC} / \mathrm{MFC}$ were the plates with lowest concentration of the compound without colony growth (NCCLS, 2000).

Isolations of the Compound: The ethyl acetate extract was purified using commercially pre-coated silica gel plate. The plant extract would be dissolved in minimum amount of ethyl acetate and was spotted at the base of the plate and developed using n-hexane and ethyl acetate (2:8). The plates was observed under the UV-lamp at $256 \mathrm{~nm}$ for the components to be separated (Cosa et al., 2006).

Column Chromatography: The ethyl acetate extract was subjected to column chromatography using Silica gel as stationary phase and ran by gradient elution technique where n-hexane and ethyl acetate were employed as mobile phase. The silica gel $100 \mathrm{~g}$ would be packed in a column $(3.5 \mathrm{~cm} \times 40 \mathrm{~cm})$ with hexane using wet method. The column would be allowed to stabilize before the extract ( $2 \mathrm{~g}$ ) adsorbed on some amount of the silica gel was packed on top of the prepared column and a cotton wool placed on the packed column. Elution began with hexane (100\%) 
and then followed by gradual introduction of ethyl acetate $(5 \%, 10 \%, 15 \%$ etc.) until ethyl acetate (100 $\%$ ) would be used. The flow rate of the column would be worked at 20 drops $/ \mathrm{min} .20 \mathrm{ml}$ aliquots were collected and analysed using TLC. The column fractions with a similar single spot indicating the isolation of a compound were pooled together dried at room temperature until a homogeneous compound was shown. Three (3) vials O-LI 43 - 45 had similar TLC profile with only two prominent spots were thus, pulled together and separated using a smaller column. A component code named O-LI was carefully taken for further analysis.

Characterization of isolated compound: The IR spectrum of the compound (O-LI) isolated from the ethyl acetate extract of Lawsonia inermis was recorded using a Nicolet 170SX. The spectral resolution for the Nicolet 170SX was $0.25 \mathrm{~cm}^{-1}$, and the spectral data were stored in the database at intervals of $0.5 \mathrm{~cm}-1$ at $4000-2000 \mathrm{~cm}^{-1}$, and of $0.25 \mathrm{~cm}^{-1}$ at $2000-400 \mathrm{~cm}^{-1} .{ }^{1} \mathrm{H}$ NMR spectra of the compound (O-LI) isolated was recorded using a JEOL AL-400 (399.65 MHz). The measuring conditions for the spectra were at flip angle of 22.5-30.0 degrees, pulse repetition time of $30 \mathrm{~s}$. The longer the pulse repetition time and the smaller the flip angle used to ensure precise relative intensities. ${ }^{13} \mathrm{C}$ NMR spectra of the compound (O-LI) isolated was recorded with a Bruker AC-200 (50.323 MHz). The measuring conditions for the spectra were as follows: a pulse flips angle of 22.45-45 degrees, a pulse repetition time of 4-7 seconds, and a resolution of 0.025-0.045 ppm. The spectra whose spectral codes started with "CDS" were reconstructed from signal positions, intensities, and line widths by assuming all resonance signals were Lorenz lines.

\section{RESULTS AND DISCUSSION}

The preliminary phytochemical screening of extracts of L. inermis showed the presence of cardiac glycosides, tannins, flavonoids, steroid and triterpenes and alkaloids in all the extracts. However, saponins tested positive in only the ethyl acetate and methanol extracts while flavonoids and tannins tested positive in all extracts except in the n-hexane (Table 1). The result of the antimicrobial screening of the extracts of the seeds of L. inermis was recorded in Table 2. The hexane extract of L. inermis showed no antimicrobial activity against all the selected microorganisms at all concentration. The chloroform extract showed activity against only S. aureus with a diameter of zones of inhibition which ranged from $12-17 \mathrm{~mm}$ at various concentration respectively. The ethyl acetate extract showed inhibition effect against $\mathrm{S}$. aureus, B. subtilis, E. coli, S. typhi and P. aeruginosa with a diameter of zone inhibition which ranged $18-26 \mathrm{~mm}$ at a concentration of $100 \mathrm{mg} / \mathrm{ml}$. At $50 \mathrm{mg} / \mathrm{ml}$, the ethyl acetate extracts showed activity with a diameter of zones of inhibition which ranged from 14-21 mm against same organisms.

Table 1: Phytochemical Constituents of the Extracts

\begin{tabular}{|c|c|c|c|c|}
\hline Metabolites and Test & $\mathrm{H}$ & $\mathrm{CF}$ & EA & MT \\
\hline $\begin{array}{ll}\begin{array}{l}\text { Anthraquinones } \\
\text { test) }\end{array} & \text { (Bontragers' }\end{array}$ & - & - & - & - \\
\hline $\begin{array}{l}\text { Cardiac glycosides } \\
\text { (Keller-Killiani test) }\end{array}$ & - & + & + & + \\
\hline Saponins (Frothing test) & - & - & + & + \\
\hline $\begin{array}{l}\text { Steroid and Triterpenes } \\
\text { (Lieberman-Buchard test) }\end{array}$ & + & + & + & + \\
\hline Tannins (Ferric chloride test) & - & + & + & + \\
\hline Flavonoid (Shinoda test) & - & + & + & + \\
\hline Alkaloids & _ & + & + & + \\
\hline
\end{tabular}

The ethyl acetate extracts showed activity against $\mathrm{S}$. aureus, B. subtilis, E. coli, S. typhi, P. aeruginosa and K. pneumonia with a zone of inhibition of $16,19,12$, 14 and $14 \mathrm{~mm}$ respectively at a concentration of 25 $\mathrm{mg} / \mathrm{ml}$. At $12.5 \mathrm{mg} / \mathrm{ml}$, the extract was only sensitive against $\mathrm{S}$. aureus, $\mathrm{B}$. subtilis and $\mathrm{K}$. pneumonia with a diameter of zones of inhibition of 14, 17 and $12 \mathrm{~mm}$. The methanol fraction showed activity against S. aureus, B. subtilis, P. aeruginosa and K. pneumonia with a diameter of zone of inhibition of 18, 24, 19 and $19 \mathrm{~mm}$. At $50 \mathrm{mg} / \mathrm{ml}$ the diameter of zone of inhibition against the selected microorganism was 16, 22, 14 and 14. At $12.5 \mathrm{mg} / \mathrm{ml}$. the extract was sensitive to $\mathrm{S}$. aureus and B. subtilis with a zones of inhibition of 12 and $16 \mathrm{~mm}$ respectively. Thin Layer Chromatographic (TLC) procedure was performed on the ethyl acetate extracts to ascertain the number of components present. This fraction was the most sensitivity to the microorganisms used. The result of the minimum inhibitory concentration of the ethyl acetate extract of the seed extract of L. inermis was $3.15 \mathrm{mg} / \mathrm{ml}$ against S. aureus, P. aeruginosa and B. subtilis, $25 \mathrm{mg} / \mathrm{ml}$ against E. coli and S. typhi and $12.5 \mathrm{mg} / \mathrm{ml}$ against $\mathrm{K}$. pneumonia. The Methanol extract had a minimum inhibition concentration of $3.125 \mathrm{mg} / \mathrm{ml}$ against $\mathrm{B}$. subtilis, $12.5 \mathrm{mg} / \mathrm{ml}$ against $\mathrm{S}$. aureus and $25 \mathrm{mg} / \mathrm{ml}$ against $\mathrm{P}$. aeruginosa and $\mathrm{K}$. pneumonia. The minimum bactericidal concentration (MBC) of the chloroform extract against S. aureus was $50 \mathrm{mg} / \mathrm{ml}$. The ethyl acetate extract has MBC value of $50 \mathrm{mg} / \mathrm{ml}$ against $\mathrm{E}$. coli and $\mathrm{S}$. typhi and $25 \mathrm{mg} / \mathrm{ml}$ against $\mathrm{K}$. pneumonia, however, it was $6.25 \mathrm{mg} / \mathrm{ml}$ against $\mathrm{S}$. aureus, B. subtilis and $\mathrm{P}$. aeruginosa. The methanol extract of L. inermis had $\mathrm{MBC}$ of $50 \mathrm{mg} / \mathrm{ml}$ against $\mathrm{P}$. aeruginosa and K. pneumonia. The MBC of methanol fraction against $\mathrm{K}$. pneumonia and $\mathrm{P}$. aeruginosa was $50 \mathrm{mg} / \mathrm{ml}$. At $25 \mathrm{mg} / \mathrm{ml}$ the MBC was against $\mathrm{S}$. aureus and $6.25 \mathrm{mg} / \mathrm{ml}$ against $\mathrm{B}$. subtilis (Table 3). 
Table 2: Zone of Inhibition (mm) of the Seeds Extracts against Test Microorganism at Varying Concentrations (mg/ml)

\begin{tabular}{|c|c|c|c|c|c|}
\hline Test organiam & $\begin{array}{l}\mathrm{H} \\
1005025 \quad 12.5\end{array}$ & $\begin{array}{l}\text { CF } \\
100502512.5\end{array}$ & $\begin{array}{l}\mathrm{EA} \\
100502512.5\end{array}$ & $\begin{array}{l}\mathrm{MT} \\
100502512.5\end{array}$ & $\begin{array}{l}\text { CPF control } \\
(\mathrm{mg} / \mathrm{ml})\end{array}$ \\
\hline S. aurens & $-\cdots$ & $\begin{array}{llll}17 & 15 & 13 & 12\end{array}$ & $221916 \quad 14$ & $181614 \quad 12$ & 30 \\
\hline B. subtilis. & $-\quad-$ & $-\quad-\quad$ & $242119 \quad 17$ & $242219 \quad 16$ & 30 \\
\hline E coli & $-\cdots$ & - & $1612--$ & $-\quad-\quad-$ & 30 \\
\hline S. tophbi & $-\ldots$ & - & $181412-$ & - - & 30 \\
\hline P. aexuginosa & - & - & $191614=$ & $191412 \quad-$ & 30 \\
\hline K. pneumonia & $\ldots$ & - - & $221914 \quad 12$ & 191412 - & 30 \\
\hline
\end{tabular}

Key: - = absent, $+=$ Present, $H=$ Hexane extract, $C F=$ Chloroform extract, $E A=$ Ethyl acetate $\quad$ extract, $M T=$ Methanol extract, $C P F=$ Ciprofloxacin

Table 3: Minimum inhibition concentration and Minimum bactericidal concentration of extracts of the seed of L. inermis

\begin{tabular}{|c|c|c|c|c|c|c|c|c|}
\hline Organism & MIC & & & & $\mathbf{M B C}$ & & & \\
\hline & $\mathrm{H}$ & $\mathrm{CF}$ & ET & MT & $\mathrm{H}$ & $\mathrm{CF}$ & ET & MT \\
\hline S. áveus. & ND & ND & 3.125 & 12.4 & $\mathrm{ND}$ & 50 & 6.25 & 25 \\
\hline B. suboilis & $\mathrm{ND}$ & $\mathrm{ND}$ & 3.125 & 3.125 & $\mathrm{ND}$ & $\mathrm{ND}$ & 6.25 & 6.25 \\
\hline E. coli & $\mathrm{ND}$ & $\mathrm{ND}$ & 25 & ND & $\mathrm{ND}$ & $\mathrm{ND}$ & 50 & ND \\
\hline S. oppli & $\mathrm{ND}$ & ND & 25 & $\mathrm{ND}$ & $\mathrm{ND}$ & $\mathrm{ND}$ & 50 & $\mathrm{ND}$ \\
\hline P. aexugizose & ND & ND & 3.125 & 25 & $\mathrm{ND}$ & ND & 6.25 & 50 \\
\hline $\boldsymbol{K}$ рneumonia & $\mathrm{ND}$ & $\mathrm{ND}$ & 12.5 & 25 & $\mathrm{ND}$ & $\mathrm{ND}$ & 25 & 50 \\
\hline
\end{tabular}

$N D=$ Not determine, $H=$ Hexane extract, $C F=$ Chloroform extract, $E A=$ Ethyl acetate extract, $M T=$ Methanol extract .

The minimum bactericidal concentration $(\mathrm{MBC})$ were carried out to determine whether the test microbes were killed or only their growth was inhibited.

Characterization of the Isolated Compound: Compound O-LI was isolated as a yellow crystalline substance $(5.3 \mathrm{mg})$ from the ethyl acetate seeds extract of L. inermis with a melting point of $156-159^{\circ} \mathrm{C}$. The structure of O-LI were elucidated using spectroscopic techniques. Silica gel column chromatography of the ethyl acetate extract of L. inermis led to the isolation of compounds O-LI. In the FTIR spectrum of compound O-LI, (Figure 1) a signal at $3421.7 \mathrm{~cm}^{-}$ ${ }^{1}$ were observed for $\mathrm{O}-\mathrm{H}$ bond. $\mathrm{C}-\mathrm{H}$ stretch for alkane were observed at $2922.2 \mathrm{~cm}^{-1}, \mathrm{C}=\mathrm{C}$ for alkene was shown at $1647.8 \mathrm{~cm}^{-1}$ and at $1718.3 \mathrm{~cm}^{-1}, \mathrm{C}=\mathrm{O}$ stretch were observed in figure 1 .

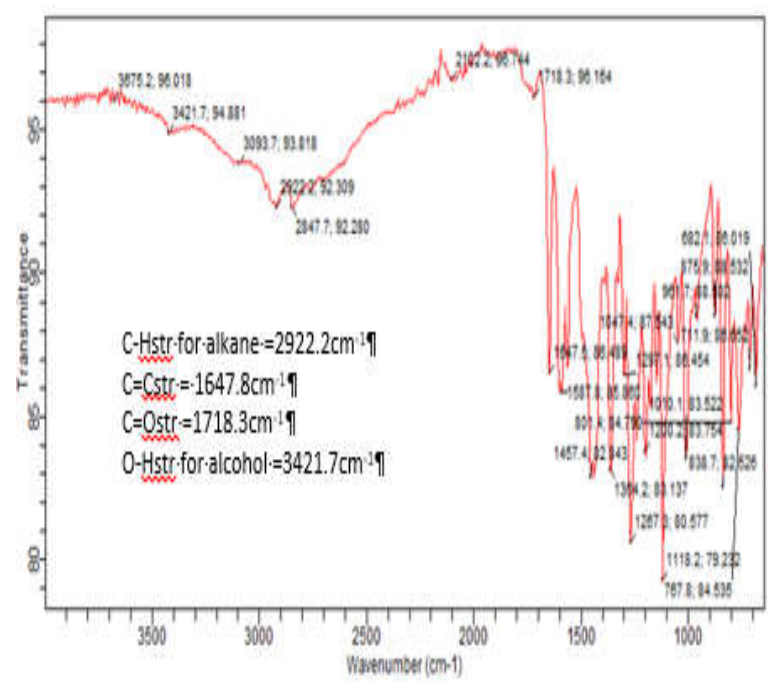

Fig 1: FT-IR Spectrum of O-LI

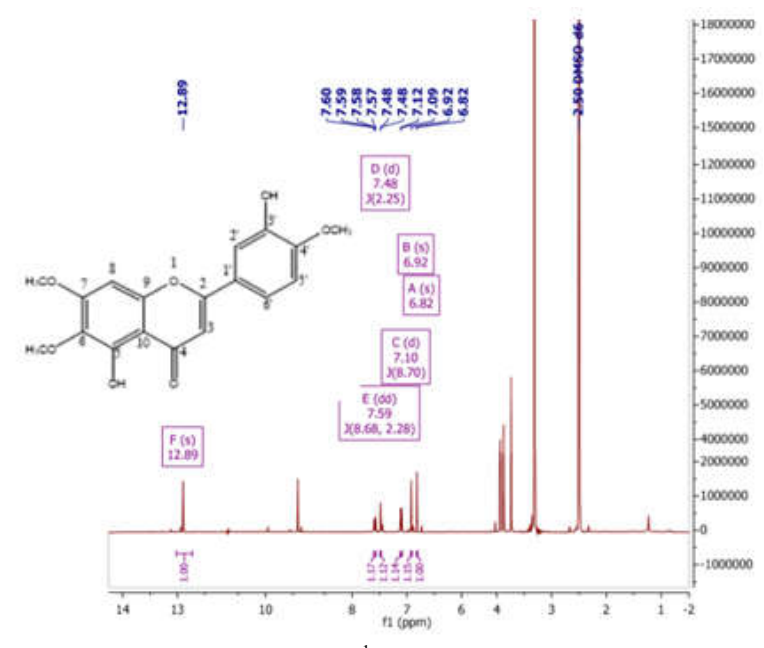

Fig2: ${ }^{1} \mathrm{H}-\mathrm{NMR}$

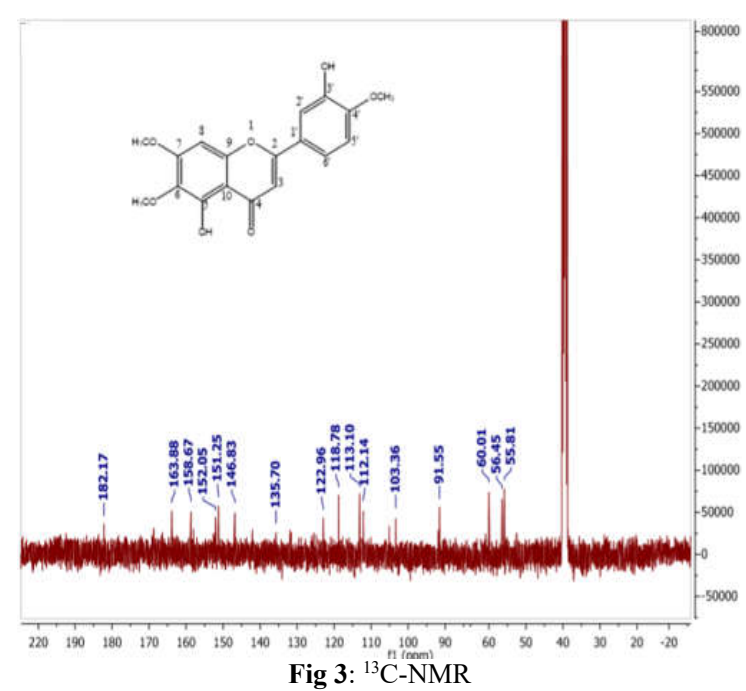


The ${ }^{1} \mathrm{H}-\mathrm{NMR}$ spectra shows signals at 3.72, 3.90 and 3.88 represents methoxy protons and signals at 12.89 and $9.49 \mathrm{ppm}$ represents $-\mathrm{OH}$ protons. Signals at 6.82 , $6.92,7.48,7.10$ and $7.59 \mathrm{ppm}$ shows aromatic moiety. ${ }^{1} \mathrm{H}-\mathrm{NMR}$ show signals at 6.82, $\mathrm{s}(\mathrm{C} 3), 6.92, \mathrm{~s}(\mathrm{C} 8)$, 7.48, s(C2'), 7.10, d(C5'), 7.59, dd(C6'), 3.72, s(6OMe $), 3.90$, s(7-OMe), 3.88, s(4'-OMe $), 12.89$, s(5$\mathrm{OH}), 9.49$, s(3'-OH). Figure 2. The ${ }^{13} \mathrm{C}$ NMR shows quaternary $\mathrm{C}-\mathrm{O}$ signals at $163.88,151.25,158.67$, 135.70, 152.05, 146.83 and 142.34. $\mathrm{C}=\mathrm{O}$ showed signal at 182.17, aromatic quaternary carbons at 103.36, 91.55, 104.14, 118.78, 113.10, 118.78 and $122.96 \mathrm{ppm}$. Signals at 56.45, 60.01 and 55.81ppm showed the presence of methoxy carbons. The ${ }^{13} \mathrm{C}$
NMR showed signals atC2 $(163.88, C)$, C3 (103.36, $\mathrm{CH},), \mathrm{C} 4(182.17, \mathrm{C}), \mathrm{C} 5(157.99, \mathrm{C}), \mathrm{C} 6(135.70, \mathrm{C})$, $\mathrm{C} 7(158.67, \mathrm{C}), \mathrm{C} 8(91.55, \mathrm{CH}), \mathrm{C} 9(151.25, \mathrm{C})$, C10(104.14, C), C1'(122.96, C), C2'(112.14, CH), C3' (146.83, C), C4'(152.05, C), C5'(113.1O, CH), C6' (118.78, CH), 6-OMe(55.81, CH), 7-OMe(60.01, $\mathrm{CH}), 4$ '-OMe $(56.45, \mathrm{CH})$. Figure 3 . Based on the FTIR, 1D and 2D NMR spectra data of compound O$\mathrm{LI}$, it was observed that $\mathrm{O}-\mathrm{LI}$ is a compound consisting of aromatic protons and a conjugated system. The spectral data values are in concordance with available literature values (Ramaraj et al., 2018). Based on the analysis above, the structure of O-LI was determined to be 3'5-hydroxy-4',6,7-trimethyoyflavone.

Table 5. NMR spectral data of O-LI and comparison with literature data

\begin{tabular}{|c|c|c|c|c|c|c|}
\hline $\begin{array}{l}\text { Carbon } \\
\text { Position }\end{array}$ & $\begin{array}{l}\text { Carbon } \\
\text { type }\end{array}$ & $\begin{array}{l}\text { Experiment } \\
{ }^{13} \mathrm{C}-\mathrm{NMR}\end{array}$ & $\begin{array}{l}{ }^{*} \text { Literatur } \\
{ }^{13} \mathrm{C}-\mathrm{NMIR}\end{array}$ & & $\begin{array}{l}\text { Experiment } \\
{ }^{1} \mathrm{H}-\mathrm{NM} \mathbf{R}\end{array}$ & $\begin{array}{l}{ }^{*} \text { Literature } \\
{ }^{1} \mathrm{H}-\mathrm{NM} \mathrm{R}\end{array}$ \\
\hline C-2 & C & $\delta 163.8$ & 164.60 & - & - & - \\
\hline C-3 & $\mathrm{CH}$ & 103.36 & 104.22 & $1 \mathrm{H}$ & 6.82 & 6.82 \\
\hline C-4 & $\mathrm{C}$ & 182.17 & 183.01 & & & \\
\hline C-5 & $\mathrm{C}$ & 157.99 & 153.40 & - & - & - \\
\hline C-6 & $\mathrm{C}$ & 135.70 & 132.44 & - & - & - \\
\hline C-7 & $\mathrm{C}$ & 158.67 & 159.54 & & & \\
\hline C-8 & $\mathrm{CH}$ & 91.55 & 92.41 & $1 \mathrm{H}$ & 6.92 & 6.91 \\
\hline C-9 & $\mathrm{C}$ & 151.25 & 152.91 & & & \\
\hline C-10 & $\mathrm{C}$ & 104.90 & 105.83 & - & - & - \\
\hline C-1', & $\mathrm{C}$ & 122.96 & 123.85 & - & - & - \\
\hline$C^{\prime} 2$ & $\mathrm{CH}$ & 112.14 & 113.05 & $1 \mathrm{H}$ & 7.48 & 7.47 \\
\hline$C^{\prime} 3$ & $\mathrm{C}$ & 146.83 & 147.72 & & & \\
\hline$C_{4}^{4}$ & $\mathrm{C}$ & 152.05 & 152.15 & & & \\
\hline$C^{\prime} 5$ & $\mathrm{CH}$ & 113.1 & 113.96 & $1 \mathrm{H}$ & 7.10 & 7.11 \\
\hline$C^{9} 6$ & $\mathrm{CH}$ & 118.78 & 119.64 & $1 \mathrm{H}$ & 7.59 & 7.60 \\
\hline 6-Ome & $\mathrm{CH}$ & 55.81 & 56.70 & $3 \mathrm{H}$ & 3.72 & 3.73 \\
\hline 7-Ome & $\mathrm{CH}$ & 60.01 & 60.90 & $3 \mathrm{H}$ & 3.90 & 3.93 \\
\hline 4-Ome & $\mathrm{CH}$ & 56.45 & 57.32 & $3 \mathrm{H}$ & 3.88 & 3.87 \\
\hline 5-OH & - & - & - & $1 \mathrm{H}$ & 12.89 & 12.91 \\
\hline $3^{1} \mathrm{OH}$ & - & - & - & $1 \mathrm{H}$ & 9.48 & 9.48 \\
\hline
\end{tabular}

Conclusion: In this study, antimicrobial activity of the crude extracts and eupatorin (3',5-dihydroxy-4',6,7trimethoxyflavone) isolated from the seed of L. inermis were assessed. The result showed positive antibacterial effects of the phytochemicals against bacterial strains testedwhich have supported the ethnomedicinal uses of this plant in the treatment of skin infections, abdominal disorders, leprosy, rheumatalgia, edema, cough and cold remedy. Further investigations are necessary to evaluate the antimycobacterial and antiviral activity of this eupatorin.

Abbreviation: $\quad$ FTIR: $\quad$ Fourier-Transform Spectroscopy; ${ }^{1} \mathrm{H}-\mathrm{NMR}$ : Proton Nuclear Magnetic Resonance; ${ }^{13} \mathrm{C}$ - NMR: Carbon-13 Nuclear Magnetic Resonance; MIC: Minimum Inhibition Concentration; MBC: Minimum Bactericidal Concentration; MFC: Minimum Fungicidal Concentration; EA: Ethyl acetate; MT: Methanol; CF: Chloroform; H: Hexane; CPF: Ciprofloxacin.

Acknowledgements: The author wishes to thank the Department of Chemistry, Ahmadu Bello University, Zaria for the laboratory and other analysis carried out.

\section{REFERENCES}

Bandyopadhyay, U; Biswas, K; Chattopadhyay, I and Banerjee, RK. (2002). Biological activities and medicinal properties of neem (Azadirachtaindica). Current Sci., 82(11):13361345

Cosa, P; Vlietinck, AJ; Berghe, DV and Maes, L (2006). Anti-infective potential of natural products: How to develop a stronger in vitro 'proof-of-concept'. J. of Ethnopharm., 106:290302 
Dey, PM and Harborne, JB. (1987). Methods in Plant Biochemistry, Academic Press, London. Pp 387416

Trease, GE and Evans, WC (1989). Pharmacognosy (13th edn). Bailliere Tindall, London, 176-180

Evans, WC (1997). An index of medicinal plants, A Text book of Pharmacognosy, 14th edition7 (5): $12-14$

Finar, G (1986). Plants of economic importance, Medicinal Plants and Medicine in Africa,Spectrum Books Ltd. Ibadan, 78:150-153

Girish, HV and Satish, S (2008). Antibacterial Activity of important medicinal plants on Human Pathogenic Bacteria- a Comparative Analysis. World Appl. Sci. J.5 (3):267-271

Harborne, JB. (1973). Phytochemical methods. A guide to modern techniques of plant analysis. Chapman and Hall Ltd, London. Pp4-7,183

Kim, WH; Camargo, MC; Chiaravalli, AM; Kim, KM; Corvalan, AH; Matsuo, K and Kijima, Y (2014). Improved survival of gastric cancer with tumour Epstein-Barr virus positivity: An international pooled analysis. Gut, 63(2): 236-243

King, R and Homsy, J (1997). Involving traditional healers in AIDS education and counselling in subSaharan Africa: a review. AIDS (London, England)

Muhammad, HS and Muhammad, S (2005). The use of Lawsoniainermis Linn. (henna) in the management of burn wound infections. Afr. J. of Biotech; 4(9): 934-937

NCCLS, 2002. Performance standard for antimicrobial susceptibility testing, $12^{\text {th }}$ informational supplements. NCCLS document M100-512. Wayne, P.A: National Commettee for Chemical Laboratory Standards

Nweze, EL; Okafor, JI and Njokn, O (2004). Antimicrobial activities of methanolic extracts of Tremaguinensis (schumm and Thom) and morinda lucida Benth used in Nigeria. Bio Res 2: $39-46$

Okwu, DE (2001). Evaluation of the chemical composition of indigenous spices and flavouring agent. Global J. Pure Appl. Sci. 7(3):455-459
Oyedeji, AO; Ekundayo, O and Koenig, WA (2005). Essential oil composition of lawsoniainermis L. leaves from Nigeria. J. of Ess. Oil Res, 17(4): 403404

Perez, C; Paul, M and Bazerque, P (1990). An Antibiotic assay by the agar well diffusion method. Acta. Bio. Med. Exp. 15:113-115

Rao, SS; Regar, PL and Singh, YV (2005). Agrotechniques for henna (Lawsoniainermis L.) cultivation, improvement and trade. Central Arid Zone Research Institute, Pali Marwar, Pp: 25-27

Reddy, KR (1988). Folk Medicine from Chittoor District, Andhra Pradesh, India, Used in the Treatment of Jaundice. Int. J. of Crude Drug Res. 26(3):137-140

Simon, JE; Chadwick, AF and Craker, LE (1984). In Herbs an indexed bibliography, Thescientific literature on selected herbs aromatic and medicinal plants of the temperate zone. Archon Books, Hamden, Pp1971-1980

Ramaraj, DJ; Rathinasamy, G and Sivasamy, VV (2018). Isoaltion of eupatorin form Albiziaodorotissima and its application for Ltryptophan sensing. Res on Chem Interm. 44: 6917-6931

Trease, GE and Evans, WC (1989). Pharmacognosy (13th edition). Bailliere Tindall, London, Pp 176180

Vineela, CH and Elizabeth, KM (2005). Antimicrobial activities of marine algae of Visakhapatnam city, Andhra Pradesh. Asian J. Microbiol. Biotech. Environ. Sci 7: 209-212

Vollekova, A; Košt'álová, D and Sochorova, R (2001). Isoquinoline alkaloids from Mahoniaaquifolium stem bark are active against Malassezia spp. Folia microbiol, 46(2):107-111

Warrier, PK (2004.) Indian medicinal plants a compendium of 500 species, Orient Longman private limited, Chennai, 3: 303-304 